\title{
肝疾患の治療歴のない高年齢層の一般住民における 肝の線維化と骨格筋量の減少との関連
}

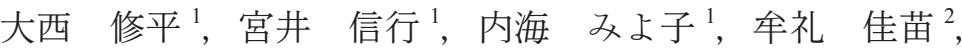 \\ 竹下 達也 ${ }^{2}$, 志波 充 $^{1}$, 有田 幹雄 $^{1}$ \\ '和歌山県立医科大学大学院保健看護学研究科 \\ 2 和歌山県立医科大学医学部公衆衛生学講座
}

\section{Liver Fibrosis is Associated with Loss of Skeletal Muscle Mass in Community-Dwelling Older Adults with No History of Liver Diseases}

\author{
Shuhei OHNISHI ${ }^{1}$, Nobuyuki MIYAI ${ }^{1}$, Miyoko UTSUMI ${ }^{1}$, Kanae MURE$^{2}$, Tatsuya TAKESHITA², \\ Mitsuru SHIBA ${ }^{1}$ and Mikio ARITA ${ }^{1}$ \\ ${ }^{1}$ Graduate School of Health and Nursing Science, Wakayama Medical University \\ ${ }^{2}$ Department of Public Health, School of Medicine, Wakayama Medical University
}

\begin{abstract}
Objectives: In this study, we aimed to examine the possible association between liver fibrosis and loss of skeletal muscle mass (SM) in community-dwelling older adults with no history of liver diseases.

Methods: A total of 2,028 older adults (mean age, $69.8 \pm 5.2$ years) who had not received any treatment for liver diseases and had participated in a comprehensive health survey for community residents in Wakayama, Japan were included in this study. We carried out bioelectrical impedance analysis to estimate the SM of the whole body including the arms, legs, and trunk of the subjects. Liver fibrosis was evaluated by calculating the Fib4 index based on the subject's age, AST level, ALT level, and platelet counts.

Results: The subjects were divided into three groups according to cutoff values of the Fib4 index (low: $<1.30$, medium: 1.30-2.66, high: $\geq 2.67)$. The $S M$ index $\left(\mathrm{kg} / \mathrm{m}^{2}\right)$ was the lowest among subjects in the high-Fib4index category, followed by the medium- and low-Fib4-index categories. This dose-response reduction in the SM index was more pronounced among individuals with lower blood albumin level (low nutrition) and in those with more sedentary behavior (physical inactivity). Among the selected 262 subjects who underwent SM measurement twice with an interval of 3 years, the subjects with a high Fib4 index showed greater reduction in the SM index than those with medium and low Fib4 indices. Multiple regression analysis revealed that the Fib4 index was significantly associated with the SM index, independent of age, sex, albumin level, sedentary behavior, diabetes mellitus, alcohol intake, and smoking status.

Conclusions: The present findings suggest that the potential progression of liver fibrosis is associated with the excessive loss of SM among apparently healthy older adults without any treatment for liver diseases.
\end{abstract}

Key words: liver fibrosis（肝線維化），Fib4 index（Fib4 インデックス）， skeletal muscle mass（骨格筋量）, older adults（高齢者), general population（一般住民）

受付 2018 年 8 月 15 日，受理 2018 年 10 月 16 日

Reprint requests to: Shuhei OHNISHI

Graduate School of Health and Nursing Science, Wakayama Medical

University, 580 Mikazura, Wakayama 641-0011, Japan

TEL: +81(73)446-6716, FAX: +81(73)446-6720

E-mail: miyain@wakayama-med.ac.jp

\section{I. 緒言}

平成 30 年の総務省の統計では, 65 歳以上の高齢者人 口は 3,529 万人に達し, 総人口に占兴割合 (高齢化率) は $27.9 \%$ となっている (1)。人口の高齢化は今後さらに 加速すると予想されており，健康寿命の延伸や介護予防 の視点から，高齢者のフレイル（虚弱）またはサルコペ 
ニアの対策が公衆衛生上の課題になっている(2)。フレ イルは, 老化に伴って様々な機能の脆弱性が立進した状 態であり, 筋力の低下, 認知機能の低下, 精神活動の低 下，生活活動の低下などの広範な要素が含まれる (3)。 一方, サルコペニアは, 骨格筋量の減少を基盤として筋 力や身体機能の低下を伴う病態であり，身体的フレイル の主たる要因を形成する $(3,4)$ 。このような高齢者に抒 ける骨格筋量の減少に対しては，加齢のみならず，身体 活動性の低下 (廃用), 栄養不良 (摂取不足や吸収不良), 筋肉を司る神経の変性, 筋肉のタンパク合成・分解に関 わる異常などが影響を及ぼすとされている(4)。

近年, 本邦に沶いては高齢化や肥満人口の増加に伴っ て, 非アルコール性脂肪性肝疾患 (nonalcoholic fatty liver disease: NAFLD) の有病率が増加傾向にある (5)。 加えて, 過剩飲酒を背景としたアルコール性肝障害の患 者数も依然として多く, 肝硬変患者の約 3 割に飲酒の関 与が疑われている(6)。肝細胞の破壊が継続して線維化 が進行すると, やがて肝機能が失われて肝硬変に至る。 また, 肝障害は筋組織に抢けるグリコーゲン貯蔵量の低 下，分岐鎖アミノ酸（branched chain amino acids: BCAA） の欠乏, ミオスタチン濃度上昇, 活性酸素々炎症性サイ トカインの増加などを誘発して骨格筋量の減少を招きや すく（7），慢性肝疾患患者ではサルコペニアの合併率が 高いことが報告されている $(8-10)$ 。一方で, 肝疾患に 起因する骨格筋量の減少やサルコペニアに関する知見の 多くは，慢性肝炎または肝硬変の治療患者を対象とする 臨床研究によるものであり, 肝疾患の治療歴のない一般 集団に拈いて, 肝機能の低下が骨格筋量の減少を招くか ぞらかを疫学的に検討した研究はみられない。また，栄 養不良や身体活動性の低下は, 加齢に伴ら骨格筋量の減 少を促進する重要なリスクであるが，肝機能の低下にこ れらの要因が併存した場合の影響を考察した研究も多く ない(11)。

そこで本研究は, 地域在住の高年齢層の一般住民を対 象に肝の線維化と骨格筋量の減少との関連, ならびに低 栄養や身体不活動との重複による複合的な影響を明らか にすることを目的とした。

\section{II. 研究方法}

\section{1. 対象者}

対象者は，わかやまへルスプロモーション研究（わか やまスタディ）に参加した和歌山県内の地域に在住する 40 歳以上の一般住民であった。わかやまスタディは, 県内の北部 - 中部 - 南部に位置する人口 15,000 人規模 の 3 町に打汀る特定健康診査执よび後期高齢者医療健康 診査の受診者を観察対象集団とする前向きコホート研究 ならびに連続横断研究であり，2011 年よりコホートの 登録が開始されている。

本研究では, $2014 \sim 2017$ 年の研究に参加した 2,488 名のらち, (1)年齢が 60 歳未満または 90 歳以上の者 $(n$
=296), (2) body mass index（BMI） が $30 \mathrm{~kg} / \mathrm{m}^{2}$ 以上の極 端な肥満者 $(n=59)$, (3)肝疾患（ウイルス性肝炎，自己 免疫性肝炎, 原発性胆汁性肝硬変, 肝硬変, 肝蔵癌) たは血液疾患（多血症，血小板減少症）の治療歴がある 者 $(n=93)$, (4)解析に必要なデータの欠損または測定工 ラーがある者 $(n=38)$ の計 460 名（条件の重複あり） を除外した 2,028 名（男性 935 名，女性 1,093 名）を対 象として, 肝の線維化と骨格筋量との関係を検討した。 さらに，2014 年に骨格筋量を測定し，3 年後の 2017 年 に再び測定を行った 262 名（男性 113 名, 女性 149 名） を対象に, 肝の線維化が骨格筋量の経年的な变化に及ぼ 寸影響について子検討を行った。

対象者には, 事前に本研究の目的, 意義, 方法, 研究 参加・撤回の自由, 個人情報の守秘管理, プライバシー の保護などについて文書と口頭で説明し，同意を得た。 また, 本研究は, 和歌山県立医科大学の倫理審査委員会 に扔いて「人を対象とする医学系研究に関する倫理指針」 に基づいた審査を受け，承認を得て実施した（承認番号 92)。

\section{2. 臨床検查}

身体計測として，身長，体重，BMI $\left(\mathrm{kg} / \mathrm{m}^{2}\right)$, 腹囲の 測定を行った。腹囲は, 立位にて通常呼吸の呼気の終わ りに臍水平面で測定した。また, 空腹状態で上腕静脈よ り採血し, 血液生化学検査を行った。本研究では, 肝機 能の指標として, AST, ALT, $\gamma$-GTP, 血小板数 (PLT) を用いた。栄養状態は, アルブミン, 総コレステロール, 総タンパクで評価し，アルブミンが基準值 $(4 \sim 5 \mathrm{~g} / \mathrm{dl})$ 未満の場合を低栄養と定義した。検査はすべて午前中に 実施し，対象者には，当日に朝食を摂取しないこと，検 査前に喫煙, 飲酒, 治療薬の内服, 激しい身体活動を避 けることを指示した。

基本属性（性別，年齢，疾患の治療歴，服薬の状況）, 哭煙，飲酒，身体活動量に関する情報は，自記式質問票 または問診によって収集した。喫煙は，現在および過去 の喫煙経験を調査した。現在喫煙者は，調査時の少なく とも 6 か月以上前から習慣的に喫煙している者とした。 飲酒は, アルコールの種類, 飲酒頻度, 1 日あたりの飲 酒量を調査して，純アルコール摂取量（g/日）を推算し た。身体活動量は，国際標準化身体活動質問票短縮版 (international physical activity questionnaire-short version: IPAQ-SV）を用いて調查した（12）。本研究では，座位 行動の時間（仕事や余暇時間などで座位または臥位での 行動に費やす時間）に焦点をあて，先行研究を参考に， 座位行動時間が 1 日あたり 8 時間以上の場合を身体不活 動と定義した (13)。

\section{3. 骨格筋量}

骨格筋量の測定には，単周波生体電気インピーダンス 法（bioelectrical impedance analysis：BIA 法）による高精 度筋量計 (Physion MD, フィジオン社製) を使用した 
(14)。本装置は, $50 \mathrm{kHz}$ の周波数, $500 \mu \mathrm{A}$ の定電流を 使用した四肢誘導 12 電極方式の身体組成計で, 磁気共 鳴画像法 (magnetic resonance imaging: MRI 法) を評価 基準とした身体各部の骨格筋量の推定が可能である。ま た，先行研究に抏いて妥当性と信頼性が検証されて扣り $(15,16)$, MRI 法で測定した筋体積との間に $r=0.9$ 以上 の強い相関を認め, 画像診断と同程度の精度で四肢筋肉 量を推定できると報告されている。

測定は，室温を安定させた室内にて仰臥位姿勢で十分 に安静を保った後に実施した。左右の上肢（第 2 中手骨 と第 3 中手骨の中間, 橈骨茎状突起と尺骨茎状突起の中 間, 腕橈関節外側）と下肢（第 2 中足骨と第 3 中足骨の 中間, 内果と外果中間, 膝部外側腓骨頭上）の各 3 力所 （計 12 か所）に電極（3M 社製 Red Dot）を貼付してイ ンピーダンスを計測し, 上肢 (上腕部と前腕部), 下肢 (大 腿部と下腿部)，体幹部の筋肉量を推定した。

本研究では，上肢と下肢の筋肉量を合計したもの を四肢骨格筋量 (appendicular skeletal muscle mass index: ASM), これに体幹部の筋肉量を加えたものを全身骨格 筋量 (skeletal muscle mass index: SM) とした。さらに, これらを身長の二乗で除し，四肢骨格筋指数 (ASM index: $\mathrm{kg} / \mathrm{m}^{2}$ ) と全身骨格筋指数 (SM index: $\mathrm{kg} / \mathrm{m}^{2}$ ) を算 出した。なお, ASM index や SM indexは体格の影響を 補正して骨格筋量を評価するための指標で $(17,18)$, Asian Working Group for Sarcopenia（AWGS）によるサル コペニアの判定基準（19）でも採用されている。

\section{4. 肝の線維化}

対象者の年齢と検査当日に空腹時採血で得られた検体 から測定したAST，ALT，PLTを用いて，次式により Fib4 index を算出した (20)。

$$
\begin{aligned}
\text { Fib4 index }= & (\mathrm{AST}[\mathrm{IU} / \mathrm{L}] \times \text { 年齢 }[\text { 歳 }]) / \operatorname{PLT}\left[10^{9} / \mathrm{L}\right] \\
& \times \sqrt{\mathrm{ALT}[\mathrm{IU} / \mathrm{L}]})
\end{aligned}
$$

Fib4 index は, 血液生化学検査データから肝線維化の 進行度を早期に予測する指標であり, NAFLD Fibrosis scoreなどの他の指標と比べて診断精度が高いことが示 されている $(21,22)$ 。Fib4 indexのカットオフ值につい ては, 肝生検による病理組織所見と対比した先行研究に おいて, 2.67 以上では肝線維化の陽性的中率が $80 \%, 1.30$ 以下では陰性的中率が $90 \%$ であることが報告されてい る(23)。これに準じて, 本研究では, 1.30 (肝線維化陰 性）と2.67（肝線維化陽性）を基準として肝線維化のレ ベルを階層化した。

\section{5. 分析方法}

肝の線維化と骨格筋量との関係を検討するために，対 象者をFib4 index のカットオフ值により 3 群（低值群： 1.30 未満, 中間值群 : 1.30 以上 2.67 未満, 高值群 : 2.67 以上）に分類した。また，肝の線維化と低栄養または身
体不活動の重複による影響を検討するために，アルブミ ンが $4.0 \mathrm{~g} / \mathrm{dl}$ 末満と $4.0 \mathrm{~g} / \mathrm{dl}$ 以上, 座位行動時間が 8 時 間未満と 8 時間以上に分類し，それぞれで Fib4 indexの 3 群を比較した。群間の比較は, 連続変数では一元配置 分散分析または Kruskal-Wallis 検定, カテゴリ一変数で は $\chi^{2}$ 検定を使用した。変数の正規性は Shapiro-Wilk 検 定で検討した。SM index 抒よびASM index の比較では, 年齢と性を共変量とした共分散分析および trend 検定を 行った。多重比較検定にはHochberg の GT2 検定を使用 した。さらに，群間の差の程度を標準化するために効果 量（effect size: ES）を算出した。骨格筋量の初回検査時 と追跡検査時の比較は対応のある $\mathrm{t}$ 検定, Wilcoxonの符 号付順位検定, McNemar 検定, 相関関係は Pearson の積 率相関係数により検討した。

骨格筋量に対する肝の線維化の独立の影響を検討する ために, SM indexまたは ASM indexを従属変数, Fib4 index を独立変数とする階層的重回帰分析を行った。こ の際は，性と年齢を補正したモデル（Model 1）と，こ れにアルブミン，座位行動時間，糖尿病の治療歴，アル コール撕取量，喫煙を追加したモデル（Model 2）を設 定した。なお，独立変数はすべてカテゴリー化したら党 でダミ一変数を作成してモデルに投入した。

統計解析には IBM SPSS ver. 22 for Windows を使用し, 統計学的有意水準は 5\%とした。

\section{III. 結果}

対象者に拈ける Fib4 index は，高值側に僅かに裾野が 広がる分布を示し, 中央值（四分領域：IQR）は, 1.68 （1.40-2.06）であった。カットオフ值により線維化レベ ルを階層化すると, 低值群 379 名 (18.7\%), 中間值群 1,466 名 $(72.3 \%$ ), 高值群 183 名（9.0\%）となった。3 群の基 本属性と臨床検査值を比較して Table 1 に示した。Fib4 index の高值群は低值群および中間值群に比べて, 男性 の割合が高く，年齢が高值であった。また，体重， BMI，腹囲が低值で，肥満 $\left(\mathrm{BMI} \geq 25 \mathrm{~kg} / \mathrm{m}^{2}\right)$ の頻度が低 く, 総コレステロールも低值を示した。さらに, 純アル コールに換算して 1 日 $20 \mathrm{~g}$ 以上を飲酒する者の割合が 高くなっていた。

性と年齢の影響を補正後に Fib4 indexの3 群における 骨格筋指数を比較した結果を Table 2 に示した。SM index と ASM index はいずれも, Fib4 index の低值群か ら高值群になるにつれて低值となり（ $P$ for trend <.001）, 群の主効果が有意であった $(P<.001)$ 。また，多重比較 検定では，すべての群の組み合わせで有意な差が認めら れた。

続いて，低栄養と身体不活動との重複による複合的な 影響を検討するために，対象者をアルブミン $(4.0 \mathrm{~g} / \mathrm{dl}$ 未満と $4.0 \mathrm{~g} / \mathrm{d}$ 以上）と座位行動時間（8 時間未満と 8 時 間以上）のそれぞれで 2 群に分類したらえで，Fib4 index の 3 群を比較した。低栄養または身体不活動の有 
Table 1 Demographic and clinical characteristics in study subjects according to Fib4 index

\begin{tabular}{|c|c|c|c|c|c|}
\hline \multirow{4}{*}{ Variables } & \multirow{4}{*}{$\begin{array}{c}\text { Overall }(n=2,028) \\
\text { Mean } \pm \text { s.d, \% } \\
\text { Median [IQR] }\end{array}$} & \multicolumn{3}{|c|}{ Fib4 index } & \multirow{4}{*}{$P^{\mathrm{c}}$} \\
\hline & & $<1.30(n=379)$ & 1.30 to $2.66(n=1,466)$ & $\geq 2.67(n=183)$ & \\
\hline & & Mean \pm s.d, $\%$ & Mean \pm s.d, $\%$ & Mean \pm s.d, $\%$ & \\
\hline & & Median [IQR] & Median [IQR] & Median [IQR] & \\
\hline \multicolumn{6}{|c|}{ Demographic and anthropometric data } \\
\hline Sex, male:female & $935: 1,093$ & $154: 225$ & $685: 781$ & $96: 87$ & .021 \\
\hline Age, yr & $69.8 \pm 5.2$ & $67.7 \pm 4.1$ & $70.0 \pm 5.1$ & $73.0 \pm 5.9$ & $<.001$ \\
\hline Body weight, $\mathrm{kg}$ & $56.7 \pm 9.9$ & $58.4 \pm 9.5$ & $56.5 \pm 9.9$ & $54.6 \pm 10.3$ & $<.001$ \\
\hline Body mass index, $\mathrm{kg} / \mathrm{m}^{2}$ & $22.5 \pm 2.8$ & $23.3 \pm 2.7$ & $22.4 \pm 2.8$ & $21.6 \pm 3.0$ & $<.001$ \\
\hline Waist circumference, $\mathrm{cm}$ & $84.1 \pm 8.6$ & $86.3 \pm 8.1$ & $83.7 \pm 8.4$ & $82.0 \pm 9.6$ & $<.001$ \\
\hline Obesity $^{a}$ & 20.4 & 26.4 & 19.6 & 14.2 & .001 \\
\hline Diabetes mellitus $^{\mathrm{a}}$ & 14.7 & 16.1 & 14.5 & 13.7 & .679 \\
\hline Current smoker & 6.6 & 7.3 & 6.3 & 7.2 & .739 \\
\hline Alcohol intake, $\geq 20 \mathrm{~g} / \mathrm{d}$ & 17.9 & 15.2 & 17.5 & 26.5 & .004 \\
\hline Sedentary, $\geq 8 \mathrm{~h} / \mathrm{d}^{\mathrm{b}}$ & 16.2 & 16.6 & 16.2 & 15.1 & .899 \\
\hline \multicolumn{6}{|l|}{ Liver function } \\
\hline Fib4 index & $1.68[1.40-2.06]$ & $1.15[1.03-1.24]$ & $1.74[1.53-2.02]$ & $3.03[2.77-3.41]$ & $<.001$ \\
\hline AST, IU/1 & 23 [19-27] & 20 [17-23] & $23[20-27]$ & 30 [24-39] & $<.001$ \\
\hline ALT, IU/1 & 18 [14-23] & 19 [15-23] & 18 [14-23] & 19 [15-25] & .061 \\
\hline$\gamma$-GTP, IU/1 & 22 [17-33] & 22 [17-32] & $22[16-32]$ & $26[18-45]$ & .002 \\
\hline PLT, $10^{4} / \mu 1$ & $22.5 \pm 5.2$ & $28.4 \pm 5.0$ & $21.7 \pm 3.9$ & $16.4 \pm 4.1$ & $<.001$ \\
\hline \multicolumn{6}{|l|}{ Nutritional status } \\
\hline Albumin, $\mathrm{g} / \mathrm{dl}$ & $4.26 \pm 0.25$ & $4.27 \pm 0.25$ & $4.26 \pm 0.26$ & $4.25 \pm 0.25$ & .703 \\
\hline Total protein, $\mathrm{g} / \mathrm{dl}$ & $7.23 \pm 0.43$ & $7.26 \pm 0.36$ & $7.22 \pm 0.44$ & $7.29 \pm 0.48$ & .022 \\
\hline Total cholesterol, mg/dl & $206.8 \pm 33.3$ & $212.4 \pm 33.5$ & $206.5 \pm 32.9$ & $197.6 \pm 34.2$ & $<.001$ \\
\hline \multicolumn{6}{|l|}{ Skeletal muscle mass } \\
\hline Arm, kg & $2.07 \pm 0.58$ & $2.07 \pm 0.59$ & $2.07 \pm 0.58$ & $2.03 \pm 0.56$ & .550 \\
\hline Leg, kg & $8.97 \pm 1.97$ & $9.07 \pm 1.98$ & $8.98 \pm 1.96$ & $8.69 \pm 1.98$ & .093 \\
\hline Trunk, kg & $9.13 \pm 2.99$ & $9.13 \pm 2.97$ & $9.15 \pm 2.99$ & $9.03 \pm 3.02$ & .886 \\
\hline $\mathrm{SM}, \mathrm{kg}$ & $20.17 \pm 5.40$ & $20.28 \pm 5.41$ & $20.20 \pm 5.39$ & $19.74 \pm 5.40$ & .517 \\
\hline ASM, kg & $11.04 \pm 2.50$ & $11.14 \pm 2.52$ & $11.05 \pm 2.45$ & $10.71 \pm 2.50$ & .154 \\
\hline $\mathrm{SM}$ index, $\mathrm{kg} / \mathrm{m}^{2}$ & $7.94 \pm 1.55$ & $8.01 \pm 1.64$ & $7.95 \pm 1.53$ & $7.74 \pm 1.56$ & .141 \\
\hline ASM index, $\mathrm{kg} / \mathrm{m}^{2}$ & $4.36 \pm 0.69$ & $4.42 \pm 0.74$ & $4.36 \pm 0.67$ & $4.22 \pm 0.71$ & .005 \\
\hline
\end{tabular}

SM, skeletal muscle mass; ASM, appendicular skeletal muscle mass; IQR, interquartile range.

${ }^{a}$ The criteria of each condition are as follows: obesity, $\mathrm{BMI} \geq 25.0 \mathrm{~kg} / \mathrm{m}^{2}$; and diabetes mellitus, fasting blood glucose $\geq 126 \mathrm{mg} / \mathrm{dl}$. Patients taking any of medication are also included.

${ }^{\mathrm{b}}$ A total time of spending the sitting and/or lying behaviors in a day.

${ }^{\mathrm{c}}$ Significant difference by ANOVA, Chi-square test, and Kruskal-Wallis test.

無に関わらず，Fib4 index が高値になるほど SM index と ASM index が低值となる連続的な関係が認められたが, 群間の差の ES は, 低栄養または身体不活動の群 (partial $\left.\eta^{2}=.039 \sim .049\right)$ の方がそれ以外の群（partial $\eta^{2}=.013$ 〜.015) よりも高值であり, Fib4 index の上昇に伴う SM index と ASM index の低下の程度が大きかった。

SM index または ASM index を従属変数, Fib4 index を 独立変数として階層的重回帰分析を行った結果を Table 3 に示した。性と年齢を補正したモデル（Model 1) に打汗 Fib4 index の標準偏回帰係数 $(\beta)$ は, 低值群 を基準として中間値群から高值群になるにつれて大きく なった。また, この関係はアルブミン, 座位行動時間, 糖尿病の治療歴, アルコール摂取量, 喫煙を追加したモ
デル（Model 2）でも有意であった。なお，このモデル では Fib4 index の他に, 性, 年齢, 座位行動時間, 契煙 が SM index または ASM index の有意な独立の規定因子 となった。

対象者のうち，2014 年と 2017 年ともに骨格筋量を測 定した 262 名に打ける初回検査時と追跡検査時の測定值 を比較して Table 4 に示した。な扬，観察期間の平均は $36.4 \pm 2.1$ か月（範囲：35～40 か月）であった。身体の 部位別の骨格筋量亡骨格筋指数は，いずれも初回検査時 と追跡検査時で有意な相関を示した $(r=.830 \sim .954)$ 。 また, 下肢筋量と ASM については, 初回検査時に比べ て追跡検査時に有意に低值を示した。

初回検査時の Fib4 index に基づいて対象者を 3 群に分 
Table 2 Skeletal muscle mass according to Fib4 index in overall subjects and in groups considering nutritional status and sedentary behavior

\begin{tabular}{|c|c|c|c|c|c|c|c|c|c|c|c|}
\hline \multirow{3}{*}{ Variables } & \multirow{3}{*}{\multicolumn{2}{|c|}{ Group }} & \multicolumn{6}{|c|}{ Fib4 index } & \multirow{3}{*}{$\begin{array}{c}P^{\mathrm{b}} \\
\text { ANOVA }\end{array}$} & \multirow{3}{*}{$\begin{array}{c}P \\
\text { Trend }\end{array}$} & \multirow{3}{*}{$\begin{array}{l}\mathrm{ES}^{\mathrm{c}} \\
\left(\eta^{2}\right)\end{array}$} \\
\hline & & & \multicolumn{2}{|r|}{$<1.30$} & \multicolumn{2}{|c|}{1.30 to 2.66} & \multicolumn{2}{|r|}{$\geq 2.67$} & & & \\
\hline & & & $n$ & Mean $(95 \% \mathrm{CI})$ & $n$ & Mean $(95 \% \mathrm{CI})$ & $n$ & Mean $(95 \% \mathrm{CI})$ & & & \\
\hline \multirow{5}{*}{$\begin{array}{l}\mathrm{SM} \text { index, } \\
\mathrm{kg} / \mathrm{m}^{2}\end{array}$} & \multicolumn{2}{|l|}{ Overall } & 379 & $\begin{array}{c}8.17 \\
(8.05,8.29)\end{array}$ & 1,466 & $\begin{array}{c}7.93 * * \\
(7.87,7.99)\end{array}$ & 183 & $\begin{array}{c}7.55^{* * * i \dagger \dagger} \\
(7.37,7.72)\end{array}$ & $<.001$ & $<.001$ & .016 \\
\hline & \multirow[t]{2}{*}{ Albumin } & $\geq 4.0 \mathrm{~g} / \mathrm{dl}$ & 347 & $\begin{array}{c}8.32 \\
(8.20,8.44)\end{array}$ & 1,318 & $\begin{array}{c}7.91^{*} \\
(7.85,7.98)\end{array}$ & 161 & $\begin{array}{c}7.51 * * * \dagger \dagger \\
(6.92,8.11)\end{array}$ & $<.001$ & $<.001$ & .013 \\
\hline & & $<4.0 \mathrm{~g} / \mathrm{dl}$ & 32 & $\begin{array}{c}8.57 \\
(8.08,9.05)\end{array}$ & 148 & $\begin{array}{c}8.02 \\
(7.80,8.25)\end{array}$ & 22 & $\begin{array}{c}7.47 * * \\
(7.29,7.65)\end{array}$ & .007 & .002 & .049 \\
\hline & \multirow[t]{2}{*}{ Sedentary ${ }^{\mathrm{a}}$} & $<8.0 \mathrm{~h} / \mathrm{d}$ & 316 & $\begin{array}{c}8.16 \\
(8.02,8.30)\end{array}$ & 1,216 & $\begin{array}{c}7.94^{*} \\
(7.89,8.01)\end{array}$ & 152 & $\begin{array}{c}7.57 * * * \dot{*} \\
(7.34,7.77)\end{array}$ & $<.001$ & $<.001$ & .014 \\
\hline & & $\geq 8.0 \mathrm{~h} / \mathrm{d}$ & 63 & $\begin{array}{c}8.13 \\
(7.89,8.38)\end{array}$ & 250 & $\begin{array}{c}7.78^{*} \\
(7.66,7.91)\end{array}$ & 31 & $\begin{array}{c}7.30^{* * \dagger} \\
(6.93,7.67)\end{array}$ & .001 & $<.001$ & .042 \\
\hline \multirow{5}{*}{$\begin{array}{l}\text { ASM index, } \\
\mathrm{kg} / \mathrm{m}^{2}\end{array}$} & Overall & & 379 & $\begin{array}{c}4.47 \\
(4.40,4.53)\end{array}$ & 1,466 & $\begin{array}{c}4.36^{* *} \\
(4.33,4.39)\end{array}$ & 183 & $\begin{array}{c}4.16^{* * * * i \dagger} \\
(4.07,4.25)\end{array}$ & $<.001$ & $<.001$ & .015 \\
\hline & Albumin & $\geq 4.0 \mathrm{~g} / \mathrm{dl}$ & 347 & $\begin{array}{c}4.49 \\
(4.43,4.46)\end{array}$ & 1,318 & $\begin{array}{c}4.35^{*} \\
(4.31,4.38)\end{array}$ & 161 & $\begin{array}{c}4.17 * * * \dot{ }+\dagger \\
(4.08,4.26)\end{array}$ & $<.001$ & $<.001$ & .013 \\
\hline & & $<4.0 \mathrm{~g} / \mathrm{dl}$ & 32 & $\begin{array}{c}4.64 \\
(4.41,4.89)\end{array}$ & 148 & $\begin{array}{c}4.38 \\
(4.27,4.49)\end{array}$ & 22 & $\begin{array}{c}4.11^{*} \\
(3.81,4.40)\end{array}$ & .013 & .003 & .043 \\
\hline & \multirow[t]{2}{*}{ Sedentary ${ }^{\mathrm{a}}$} & $<8.0 \mathrm{~h} / \mathrm{d}$ & 316 & $\begin{array}{c}4.47 \\
(4.40,4.54)\end{array}$ & 1,216 & $\begin{array}{c}4.37^{*} \\
(4.33,4.40)\end{array}$ & 152 & $\begin{array}{c}4.17 * * * \dagger \dagger \\
(4.07,4.27)\end{array}$ & $<.001$ & $<.001$ & .015 \\
\hline & & $\geq 8.0 \mathrm{~h} / \mathrm{d}$ & 63 & $\begin{array}{c}4.43 \\
(4.30,4.56)\end{array}$ & 250 & $\begin{array}{c}4.29 \\
(4.23,4.35)\end{array}$ & 31 & $\begin{array}{c}4.06^{* *} \\
(3.88,4.25)\end{array}$ & .008 & .002 & .039 \\
\hline
\end{tabular}

SM, skeletal muscle mass; ASM, appendicular skeletal muscle mass; CI, confidence interval; ES, effect size.

${ }^{a}$ A total time of spending the sitting and/or lying behaviors in a day.

${ }^{\mathrm{b}}$ Significant difference after adjusting for age and sex.

${ }^{\mathrm{c}}$ Effect size was estimated with partial $\eta^{2}$. The threshold for interpreting ES was small $\left(\eta^{2}=.01\right)$, medium $\left(\eta^{2}=.06\right)$, and large $\left(\eta^{2}=.14\right)$.

${ }^{*} P<.05,{ }^{* *} P<.01,{ }^{* * *} P<.001$ (vs. $<1.30$ ), ${ }^{\dagger \dagger} P<.01,{ }^{\dagger \dagger} P<.001$ (vs. 1.30 to 2.66 ) by Hochberg's GT2 correction for multiple comparisons.

類し，研究期間中の骨格筋指数の変化量（追跡検査時の 値一初回検査時の值) を比較して Table 5 に示した。性, 年齢, 初回検査時の值を補正したモデル, これに追跡期 間，糖尿病の治療歴，アルブミン，座位行動時間，アル コール摂取量，契煙を補正したモデルのいずれにおいて も, Fib4 index の低值群から高值群になるにつれて SM index またはASM index の低下量が大きくなる変化がみ られ, SM index では群の主効果および傾向性が有意と なった。また, 多重比較検定では, 低值群と中間值群お よび高值群との間に有意な差が認められた。

\section{IV. 考察}

地域在住の一般住民のらち, 肝疾患の治療歴のない 60 歳以上の高年齢層の集団を対象として, 肝の線維化 が骨格筋量の減少に及ぼす影響を検討した。肝線維化の 指標の Fib4 index で階層化した群間を比較した結果, SM index や ASM index は, Fib4 index が高值になるにつ れて連続的に低值となった。さらに, Fib4 indexは性, 年齢, アルブミン, 座位行動時間, 糖尿病の治療歴, ア ルコール摂取量, 喫煙の補正後も SM index や ASM index の有意な独立の規定因子となった。このとから，
肝の線維化の進行は骨格筋量の減少をもたらす要因とな ることが示唆された。さらに，低栄養または身体不活動 との重複による複合的な影響を検討するために, アルブ ミンと座位行動時間で対象者を分類して Fib4 index の 3 群を比較した結果，低栄養や身体不活動の状態にある方 が，Fib4 indexの上昇に伴ら SM index やASM index の 低下の程度が大きかった。したがって, 肝の線維化に低 栄養や身体不活動の状態が併存することで骨格筋量減少 のリスクが増大する可能性も示された。

本研究では, 肝疾患の治療歴のない一般集団における 肝機能の評価に Fib4 index を使用した。Fib4 index は肝 線維化の進行度の予測指標であり，年齢，ALT，AST, PLT で算定される (20)。肝疾患のスクリーニングとし て最も初期に提唱されたモデルはAST/ALT 比で, 肝硬 変の診断に有用とされてきた。しかし，AST と ALTが 正常域でも肝の線維化が進行している場合があり感度が 低いことから，AST/ALT 比に加えてPLTを加味するこ とが望ましいとされている(24)。肝線維化の鑑別のた めのスコアリングシステムとしては, Fib4 indexの他に NAFLD fibrosis score(25)，BARD score(26)などが主に 用いられている。NAFLD fibrosis score は線維化の陰性 的中度は良好であるものの, 陽性的中度が低いことが示 
Table 3 Multiple regression analysis to determine independent association between Fib4 index and skeletal muscle mass in study subjects

\begin{tabular}{|c|c|c|c|c|c|}
\hline \multirow{3}{*}{ Variables } & \multirow{3}{*}{$n$} & \multicolumn{2}{|c|}{ SM index, $\mathrm{kg} / \mathrm{m}^{2}$} & \multicolumn{2}{|c|}{ ASM index, $\mathrm{kg} / \mathrm{m}^{2}$} \\
\hline & & Model $1^{\mathrm{b}}$ & Model $2^{c}$ & Model $1^{\mathrm{b}}$ & Model $2^{c}$ \\
\hline & & $\beta$ & $\beta$ & $\beta$ & $\beta$ \\
\hline \multicolumn{6}{|l|}{ Fib4 index } \\
\hline$<1.30$ (reference) & 379 & & & & \\
\hline 1.30 to 2.66 & 1,466 & $-.061^{*}$ & $-.063 *$ & $-.064 * *$ & $-.067 * *$ \\
\hline$\geq 2.67$ & 183 & $-.107 * * *$ & $-.110 * * *$ & $-.122 * * *$ & $-.125 * * *$ \\
\hline \multicolumn{6}{|l|}{ Age, yr } \\
\hline$<75$ (reference) & 1,751 & & & & \\
\hline$\geq 75$ & 277 & $-.052 * *$ & $-.051^{* *}$ & -.027 & $-.036^{*}$ \\
\hline \multicolumn{6}{|l|}{ Sex } \\
\hline Females (reference) & 1,093 & & & & \\
\hline Males & 935 & $.657^{* * *}$ & $.654 * * *$ & $.512 * * *$ & $.507^{* * *}$ \\
\hline \multicolumn{6}{|l|}{ Albumin, $\mathrm{g} / \mathrm{dl}$} \\
\hline$\geq 4.0$ (reference) & 1,826 & & & & \\
\hline$<4.0$ & 202 & & -.016 & & -.032 \\
\hline \multicolumn{6}{|l|}{ Sedentary, $\mathrm{h} / \mathrm{d}^{\mathrm{a}}$} \\
\hline$<8.0$ (reference) & 1,684 & & & & \\
\hline$\geq 8.0$ & 344 & & $-.037^{*}$ & & $-.041 *$ \\
\hline \multicolumn{6}{|l|}{ Diabetes mellitus } \\
\hline Absent (reference) & 1,729 & & & & \\
\hline Present & 299 & & .014 & & .016 \\
\hline \multicolumn{6}{|l|}{ Alcohol intake, $g / d$} \\
\hline$<20$ (reference) & 1,662 & & & & \\
\hline$\geq 20$ & 366 & & .033 & & .033 \\
\hline \multicolumn{6}{|l|}{ Smoking } \\
\hline Never/Former (reference) & 1,864 & & & & \\
\hline Current & 144 & & $-.056^{* *}$ & & $-.050 *$ \\
\hline Adjusted $R^{2}$ & & $.432 * * *$ & $.436^{* * *}$ & $.365^{* * *}$ & $.370^{* * *}$ \\
\hline
\end{tabular}

SM, skeletal muscle mass; ASM, appendicular skeletal muscle mass; $\beta$, partial regression coefficient. All variables were categorized and entered into the model as a dummy variable ( 0 or 1$)$.

${ }^{a}$ A total time of spending the sitting and/or lying behaviors in a day.

${ }^{\mathrm{b}}$ Adjusting for age and sex.

${ }^{\mathrm{c}}$ Adjusting for age, sex, albumin, sedentary behavior, diabetes mellitus, alcohol intake, and smoking.

$* P<.05, * * P<.01, * * * P<.001$

されている。BARD score は計算式にBMI を含んでいる が，日本人は欧米人に比べて BMI が低いことから有用 性が疑問視されている。また, Fib4 index の予測能を検 証した先行研究では, NAFLD fibrosis scoreやBARD score を含む他の指標と比べて最も診断精度に優れるこ とが報告されている $(21,22)$ 。さらに, 本研究に执いて, Fib4 index は骨格筋量の減少とも有意な関連を示したこ とから，一般集団を対象とする肝の線維化の早期発見の みならず，骨格筋量の過度の減少やそれに伴らサルコペ ニアの予防対策においても有益な情報として活用しらる ものと考光られる。

今回，Fib4 indexによる肝の線維化は低栄養や身体不 活動などの他の要因とは独立に SM index や ASM index と関連した。慢性肝炎や肝硬変の治療患者では骨格筋量
の減少が大きく，サルコペニアの合併率が高いとする臨 床成績は多く認められるが (8-10), 本研究の結果は, 一 般集団に扣いても肝線維化の進行が骨格筋量の減少に影 響することを示唆するものであった。肝疾患患者では, 肝臓でのグリコーゲン貯蔵量の低下に伴って，骨格筋か ら BCAA を含むアミノ酸とグリコーゲンの供給が増え るため，骨格筋の崩壊が進行しやすいとされる(27)。ま た，BCAA は必須アミノ酸の中でも最も蛋白質同化作用 が強いとされ，肝硬変患者で特にロイシンが欠乏した状 態では骨格筋量が正常に維持されにくいことが報告され ている $(28,29)$ 。病理組織所見と対比した先行研究では, Fib4 index が 2.67 以上の場合， $80 \%$ V F3（高度）から F4 (肝硬変) のステージの線維化がみられるとされてい る(23)。それ以前の F1（軽度）から F2（中等度）のス 
Table 4 Demographic characteristics and skeletal muscle mass at baseline and follow-up examinations in selected study subjects for longitudinal analysis $(n=262)$

\begin{tabular}{|c|c|c|c|c|}
\hline \multirow[b]{2}{*}{ Variables } & Baseline & Follow-up & \multirow[b]{2}{*}{$P^{\mathrm{b}}$} & \multirow[b]{2}{*}{$r^{\mathrm{c}}$} \\
\hline & $\begin{array}{l}\text { Mean } \pm \text { s.d, \% } \\
\text { Median [IQR] }\end{array}$ & $\begin{array}{l}\text { Mean } \pm \text { s.d, \% } \\
\text { Median [IQR] }\end{array}$ & & \\
\hline Age, yr & $66.9 \pm 3.5$ & $69.9 \pm 3.5$ & $<.001$ & \\
\hline Body mass index, $\mathrm{kg} / \mathrm{m}^{2}$ & $22.5 \pm 2.6$ & $22.3 \pm 2.7$ & $<.001$ & \\
\hline Fib4 index & $1.58[1.34-1.97]$ & $1.66[1.39-1.98]$ & .005 & \\
\hline Current smoker & 6.1 & 4.2 & .180 & \\
\hline Alcohol intake, $\geq 20 \mathrm{~g} / \mathrm{d}$ & 17.2 & 14.9 & .345 & \\
\hline Sedentary, $\geq 8 \mathrm{~h} / \mathrm{d}^{\mathrm{a}}$ & 16.4 & 13.4 & .243 & \\
\hline Arm, $\mathrm{kg}$ & $2.06 \pm 0.56$ & $2.07 \pm 0.57$ & .084 & .954 \\
\hline Leg, $\mathrm{kg}$ & $9.18 \pm 1.97$ & $9.00 \pm 1.91$ & .002 & .889 \\
\hline Trunk, kg & $9.10 \pm 2.78$ & $9.09 \pm 2.90$ & .852 & .942 \\
\hline $\mathrm{SM}, \mathrm{kg}$ & $20.33 \pm 5.19$ & $20.17 \pm 5.23$ & .171 & .943 \\
\hline ASM, kg & $11.24 \pm 2.48$ & $11.07 \pm 2.43$ & .010 & .918 \\
\hline $\mathrm{SM}$ index, $\mathrm{kg} / \mathrm{m}^{2}$ & $7.91 \pm 1.47$ & $7.89 \pm 1.46$ & .735 & .891 \\
\hline ASM index, $\mathrm{kg} / \mathrm{m}^{2}$ & $4.39 \pm 0.68$ & $4.35 \pm 0.65$ & .134 & .830 \\
\hline
\end{tabular}

SM, skeletal muscle mass; ASM, appendicular skeletal muscle mass; IQR, interquartile range.

${ }^{a} \mathrm{~A}$ total time of spending the sitting and/or lying behaviors in a day.

${ }^{\mathrm{b}}$ Significant difference by paired $t$ test, Wilcoxon signed-ranks test, and McNemar test.

${ }^{\mathrm{c}}$ Pearson's product moment correlation coefficient.

Table 5 Changes in skeletal muscle mass from baseline to follow-up in selected subjects according to Fib4 index

\begin{tabular}{|c|c|c|c|c|c|c|c|}
\hline \multirow{3}{*}{ Variables } & & \multicolumn{3}{|c|}{ Fib4 index } & \multirow{3}{*}{$P$ ANOVA } & \multirow{3}{*}{$P$ Trend } & \multirow{3}{*}{$\mathrm{ES}^{\mathrm{c}}\left(\eta^{2}\right)$} \\
\hline & & $<1.30(n=48)$ & 1.30 to $2.66(n=188)$ & $\geq 2.67(n=26)$ & & & \\
\hline & & Mean $(95 \% \mathrm{CI})$ & Mean $(95 \% \mathrm{CI})$ & Mean $(95 \% \mathrm{CI})$ & & & \\
\hline \multirow[t]{2}{*}{$\mathrm{SM}$ index, $\mathrm{kg} / \mathrm{m}^{2}$} & Model $1^{\text {a }}$ & $\begin{array}{c}0.21 \\
(0.04,0.39)\end{array}$ & $\begin{array}{c}-0.04^{*} \\
(-0.13,0.05)\end{array}$ & $\begin{array}{c}-0.24 * * \\
(-0.47,-0.01)\end{array}$ & .006 & .003 & .039 \\
\hline & Model $2^{b}$ & $\begin{array}{c}0.22 \\
(-0.08,0.52)\end{array}$ & $\begin{array}{c}-0.21^{*} \\
(-0.36,-0.06)\end{array}$ & $\begin{array}{c}-0.41^{*} \\
(-0.88,-0.05)\end{array}$ & .024 & .027 & .071 \\
\hline \multirow[t]{2}{*}{ ASM index, $\mathrm{kg} / \mathrm{m}^{2}$} & Model $1^{\mathrm{a}}$ & $\begin{array}{c}0.03 \\
(-0.22,0.28)\end{array}$ & $\begin{array}{c}-0.19 \\
(-0.31,-0.07)\end{array}$ & $\begin{array}{c}-0.30 \\
(-0.64,0.03)\end{array}$ & .197 & .114 & .013 \\
\hline & Model $2^{b}$ & $\begin{array}{c}0.02 \\
(-0.42,0.47)\end{array}$ & $\begin{array}{c}-0.48 \\
(-0.70,-0.25)\end{array}$ & $\begin{array}{c}-0.49 \\
(-1.18,0.21)\end{array}$ & .139 & .228 & .038 \\
\hline
\end{tabular}

SM, skeletal muscle mass; ASM, appendicular skeletal muscle mass; CI, confidence interval; ES, effect size.

${ }^{a}$ Model 1: Adjusting for age, sex, and baseline values.

${ }^{\mathrm{b}}$ Model 2: Adjusting for age, sex, baseline values, follow-up period, diabetes mellitus, albumin, sedentary behavior, alcohol intake, and smoking.

${ }^{\mathrm{c}}$ Effect size was estimated with partial $\eta^{2}$. The threshold for interpreting ES was small $\left(\eta^{2}=.01\right)$, medium $\left(\eta^{2}=.06\right)$, and large $\left(\eta^{2}=.14\right)$.

$* P<.05, * * P<.01$ (vs. $<1.30$ ) by Hochberg's GT2 correction for multiple comparisons

テージでは線維化に伴う臓器の損害はあるものの, 正常 な肝細胞による代償が可能な段階であるため肝機能は喪 失されにくい。しかし，F3 以後のステージでは代償能力 が低下するため, 前述した機序が複合的な要因として作 用して骨格筋量の減少をもたらしたものと推察される。 また，その他の機序として，肝硬変患者では骨格筋形成 を促進するテストステロンの減少 (30), 逆に, 骨格筋形 成を強力に抑制するミオスタチンの上昇が認められると されている(31)。また, 本研究に执いて, Fib4 indexが 2.67 以上の群では，純アルコールに換算して 1 日 $20 \mathrm{~g}$ 以上の飲酒者が有意に高率であった。過剰飲酒は肝の線 維化の重要な誘因であるが，それと同時にミオスタチン の発現を増加させることも明らかにされている(32)。
アルブミンが $4 \mathrm{~g}$ 末満の場合を低栄養と定義し，肝の 線維化との重複による複合的な影響を検討した。その結 果, 低栄養で Fib4 index が 2.67 以上の群で SM indexや ASM index が最も低值となり，低栄養と肝の線維化の併 存によって骨格筋量の減少のリスクが高まることが示唆 された。高齢者では老化とともに蛋白質の合成能が低下 するが (33)，低栄養によって蛋白質やアミノ酸の供給 が不足すると蛋白質の合成がさらに抑制される。また, 低栄養の状態が持続すると, 蛋白質を分解してエネル ギーに変換する働きも克進する。前述のように，肝障害 は肝蔵のグリコーゲンの貯蔵量の減少や蛋白質同化作用 の低下を招いて筋細胞での蛋白質の分解を促進させるこ とから (27), これらが複合的に影響して骨格筋量の減 
少に繋がったものと推察される。な牧, Fib4 index が 2.67 未満の場合には低栄養の群の方が, むしろ SM index や ASM index が高值を示す傾向にあった。この点に関して, 今回はアルブミンを低栄養の指標としたが, 先行研究で も同様に，一般集団に拈いてアルブミンはサルコペニア の重症度との間に連続的な関係を認めなかったと報告さ れている(34)。一方で, 肝硬変患者に拈いてはアルブ ミンの減少が骨格筋の萎縮と強く相関することが明らか にされている(35)。これらをふまえると，アルブミン は肝機能の低下がある程度進行した後に骨格筋量との関 係が明確になる可能性があると考えられる。

身体活動性の低下も, 低栄養と同様に蛋白質の合成と 分解のアンバランスから, 筋蛋白質の不足を招いて骨格 筋量を減少させる。高齢者では加齢による筋線維数の減 少や筋線維自体の萎縮がみられるが, 身体不活動の状態 が続くことで筋線維の萎縮が加速することになる。本研 究でも肝線維化のレベルに関わらず，座位行動時間が 8 時間以上の群では SM index や ASM index が一貫して低 值を示したことから, 身体不活動は骨格筋量の減少に強 く影響を及ぼすものと考兄られる。また，身体不活動の 状態にある方が Fib4 index の上昇に伴うSM index や ASM index の低下の程度が相対的に大きかった。肝硬変 患者を対象とした先行研究では, 歩行数の減少がサルコ ペニアの危険因子であり, 肝疾患に身体不活動が重複す ると骨格筋の萎縮が増強されることが示唆されている (11)。本研究では, 肝疾患の治療歴のない一般集団を対 象としたが, 肝の線維化の進行が筋細胞中の蛋白質の合 成能に影響を与え, 身体不活動による骨格筋量の減少を さらに高めたものと推察される。

骨格筋量を複数回測定できた集団を対象に, 肝の線維 化が骨格筋量の経年的変化に及ぼす影響を検討した結 果, Fib4 index の高值群では低值群に比べて, 初回検査 時から追跡検査時にかけての SM index の低下量が有意 に大きくなっていた。このことは, 肝の線維化が骨格笳 量の減少を招く要因として重要であることをさらに支持 するものと考兄らる。なお，この検討において，肝の 線維化と骨格笳量の減少の関係は ASM index に比べて SM index でより明確に認められた。この点についての 妥当な解釈は容易ではないものの, 対象集団において ASM は初回時から追跡時にかけて有意に減少していた のに対して SM ではその減少率が相対的に小さかった。 このため, 加齢に伴ら変化が少ないことで, 肝の線維化 が骨格筋量の減少に及ぼす影響がより検出されやすかっ たのではないかと推察される。

本研究では, BIA 法による身体組成計を用いて, 上肢, 下肢, 体幹部のインピーダンスを計測して筋肉量を推定 した（14）。本装置は, MRI 法で測定した筋体積と高い 相関を示し, 画像診断と同程度の精度で筋肉量を推定で きることが示されている $(15,16)$ 。な拈，BIA 法はイン ピーダンスから推定式を用いて骨格筋量を測定するた め, 機種によって測定結果に差違が生じる。BIA 法で
は, MRI 法か二重 X 線吸収測定法 (dual energy X-ray absorptiometry : DEXA 法）のいずれかを基準として推 定式が作成されているが，DEXA 法は，骨格筋内に浸潤 した脂肪，皮膚直下の血液，リンパ液，骨髄液などの体 水分成分が含まれるため, MRI 法に比べて骨格筋量を 過大評価することが知られている(36)。このため，同 じBIA 法であっても両者の間で測定結果を単純に比較 することはできない。また, AWGSによるサルコペニ アの判定基準 (19) に採用されているカットオフ值は DEXA 法を基準とする機種によるものであるため，MRI 法を基準とする機種での測定結果を適用できない点にも 注意する必要がある。

最後に，本研究の限界点として，まず，対象者は和歌 山県内の非都市部の複数地域に在住する住民のらち, 特 定健康診査抢よび後期高齢者医療健康診査を受診した選 択的な集団である。また，肝線維化による影響をより明 確にするために，骨格筋量の減少率が同程度である 60 歳代から 80 歳代の年齢層に限定していることから, 研 究成果の一般化は慎重でなければならない。本研究では, 肝の線維化の進行が骨格筋量の減少に繋がること, 低栄 養と身体不活動の状態が併存とそのリスクが増大するこ とを示唆する結果を得たが，これらは主として横断的な 解析に基づくものであるため, 因果に関する時間的な前 後関係の評価は難しい。このため, 骨格筋量を複数回測 定した一部の集団を対象に縦断的な解析も行ったが，観 察期間が短く，サンプル数も十分でないため，今後も追 跡調査を継続して解析結果の信頼性を検証する必要があ る。さらに, 骨格筋量の減少を誘発する要因は多岐にわ たり, 身体活動性や栄養状態の他にも, 臓器障害, 悪性 腫瘍, 炎症性疾患, 内分泌疾患などの疾病が関与する場 合もある。本研究の対象者には, 重症の臓器障害や悪性 腫瘍の進行例は含まれていないものの, 軽微な状態も含 めるとこれらの疾病の保有者を完全に除外することはで きていない。加えて, 肝の線維化と骨格筋量の関係を分 析する際には, 数学的モデリングによって想定される交 絡因子は補正したが，その影響をすべて排除することは 困難であるため，両者の関係に何らかのバイアスが介在 した可能性は否定できない。

\section{V. 結 論}

加歯に伴い骨格筋量の減少と筋力・身体機能の低下が 全身性に進行するサルコペニアは，フレイルや転倒・骨 折と密接に関連することから要介護状態に至る要因とな り, 健康寿命の延伸を目指すらえでも重要な病態である。 本研究から, 慢性肝炎や肝硬変の治療患者のみならず, 一般集団に拈いても肝の線維化の進行が骨格筋量の減少 に関連することが明らかになった。また，低栄養や身体 不活動の状態にある者に肝機能の低下が併存する場合, 骨格筋量の減少のリスクがさらに高くなる可能性も示さ れた。これらは, 高齢者に抢ける骨格筋量の過度の減少 
を抑制するらえで肝機能を正常に維持することの重要性 を示唆するもので, サルコペニアやフレイルの予防対策 に貢献できる有益な知見となるものと考它られる。

本研究に関連して開示すべき利益相反はない。

\section{文献}

（1）総務省統計局. 人口推計 (平成 30 年 7 月報), 2014 . https://www.stat.go.jp/data/jinsui/pdf/201807.pdf（参照 2018.7.25)

（2）今井博久. 2025 問題とは何か：公衆衛生が直面する 問題の諸相. 保健医療科学 2016;65:2-8.

(3) 荒井秀典. フレイルの意義. 日本老年医学会雑誌 2014;51:497-501.

（4）葛谷雅文. サルコペニアの診断・病態・治療. 日本老 年医学会雑誌 2015;52:343-349.

( 5 ) Eguchi Y, Hyogo H, Ono M, Mizuta T, Ono N, Fujimoto K, et al. Prevalence and associated metabolic factors of nonalcoholic fatty liver disease in the general population from 2009 to 2010 in Japan: a multicenter large retrospective study. J Gastroenterol 2012;47:586-595.

( 6 ) Kikuchi M, Horie Y, Ebinuma H, Taniki N, Nakamoto N, Kanai T. Alcoholic liver cirrhosis and significant risk factors for the development of alcohol related hepatocellular carcinoma-Japan, 2012. Jpn J Alcohol \& Drug Dependence 2015;50:222-234.

（7）西口修平, 日野啓輔, 森屋恭爾, 白木 亮, 平松 憲, 西川浩樹. 日本肝臓学会サルコペニア判定基準作成 ワーキンググループ. 肝疾患に打けるサルコペニアの 判定基準 (第 1 版). 肝臓 2016;57:353-368.

( 8 ) Hanai T, Shiraki M, Ohnishi S, Miyazakai T, Ideta T, Kochi $\mathrm{T}$, et al. Rapid skeletal muscle wasting predicts worse survival in patients with liver cirrhosis. Hepatol Res 2016;46: 743-751.

(9) Harimoto N, Shirabe K, Yamashita YI, Ikegami T, Yoshizumi T, Soejima Y, et al. Sarcopenia as a predictor of prognosis in patients following hepatectomy for hepatocellular carcinoma. Br J Surg 2013;100:1523-1530.

(10) Kamachi S, Mizuta T, Otsuka T, Nakashita S, Ide Y, Miyoshi A, et al. Sarcopenia is a risk factor for the recurrence of hepatocellular carcinoma after curative treatment. Hepatol Res 2016;46:201-208.

(11) Hayashi F, Matsumoto Y, Momoki C, Yuikawa M, Okada G, Hamakawa E, et al. Physical inactivity and insufficient dietary intake are associated with the frequency of sarcopenia in patients with compensated viral liver cirrhosis. Hepatol Res 2013;43:1264-1275.

（12）村瀬訓生, 勝村俊仁, 上田千穂子, 井上 茂, 下光輝 一. 身体活動量の国際標準化一IPAQ 日本語版の信頼 性, 妥当性の評価一. 厚生の指標 2002;49:1-9.

(13) van der Ploeg HP, Chey T, Korda RJ, Banks E, Bauman A. Sitting time and all-cause mortality risk in 222497 Australian adults. Arch Intern Med 2012;172:494-500.

(14) Tanaka N, Miyatani M, Masuo Y, Fukunaga T, Kanehisa H. Applicability of a segmental bioelectrical impedance analy- sis for predicting the whole body skeletal muscle volume. J Appl Physiol 2007;103:1688-1695.

(15) Yonei Y, Miwa Y, Hibino S, Takahashi Y, Miyazaki R, Yoshikawa T, et al. Japanese Anthropometric reference data - special emphasis on bioelectrical on bioelectrical impedance analysis of muscle mass. Anti-Ageing Medicine 2008; 5:63-72.

(16) Miyatani M, Kanehisa H, Masuo Y, Ito M, Fukunaga T. Validity of estimating limb muscle volume by bioelectrical impedance. J Appl Physiol 2001;91:386-394.

(17) Baumgartner RN, Koehler KM, Gallagher D, Romero L, Heymsfield SB, Ross RR, et al. Epidemiology of sarcopenia among the elderly in New Mexico. Am J Epidemiol 1998;147:755-763.

(18) Janssen I, Baumgartner RN, Ross R, Rosenberg IH, Roubenoff R. Skeletal muscle cutpoints associated with elevated physical disability risk in older men and women. Am J Epidemiol 2004;159:413-421.

(19) Chen LK, Liu LK, Woo J, Assantachai P, Auyeung TW, Bahyah KS, et al. Sarcopenia in Asia: consensus report of the Asian Working Group for Sarcopenia. J Am Med Dir Assoc 2014;15:95-101.

(20) Sterling RK, Lissen E, Clumeck N, Sola R, Correa MC, Montaner J, et al. Development of a simple noninvasive index to predict significant fibrosis in patients with $\mathrm{HIV} / \mathrm{HCV}$ coinfection. Hepatology 2006;43:1317-1325.

(21) Yang HR, Kim HR, Kim MJ, Ko JS, Seo JK. Noninvasive parameters and hepatic fibrosis scores in children with nonalcoholic fatty liver disease. World J Gastroenterol 2012;18: 1525-1530.

(22) Sumida Y, Yoneda M, Hyogo H, Itoh Y, Ono M, Fujii H, et al; Japan Study Group of Nonalcoholic Fatty Liver Disease (JSG-NAFLD). Validation of the Fib4 index in a Japanese nonalcoholic fatty liver disease population. BMC Gastroenterol 2012;12:2.

(23) Shah AG, Lydecker A, Murray K, Tetri BN, Contos MJ, Sanyal AJ; Nash Clinical Research Network. Comparison of noninvasive markers of fibrosis in patients with nonalcoholic fatty liver disease. Clin Gastroenterol Hepatol 2009; 7:1104-1112.

（24）岡上 武, 水野雅之. 肝機能検査, 肝障害について 一健診に打ける問題点. 総合健診 2015;42:307-312.

(25) Angulo P, Hui JM, Marchesini G, Bugianesi E, George J, Farrell GC, et al. The NAFLD fibrosis score: a noninvasive system that identifies liver fibrosis in patients with NAFLD. Hepatology 2007;45:846-854.

(26) Harrison SA, Oliver D, Arnold HL, Gogia S, NeuschwanderTetri BA. Development and validation of a simple NAFLD clinical scoring system for identifying patients without advanced disease. Gut 2008;57:1441-1447.

(27) Moriwaki H, Miwa Y, Tajika M, Kato M, Fukushima H, Shiraki M. Branched-chain amino acids as a protein- and energy-source in liver cirrhosis. Biochem Biophys Res Commun 2004;313:405-409.

(28) Katsanos CS, Kobayashi H, Sheffield-Moore M, Aarsland A, Wolfe RR. A high proportion of leucine is required for optimal stimulation of the rate of muscle protein synthesis by 
essential amino acids in the elderly. Am J Physiol Endocrinol Metab 2006;291:E381-387.

(29) Børsheim E, Bui QU, Tissier S, Kobayashi H, Ferrando AA, Wolfe RR. Effect of amino acid supplementation on muscle mass, strength and physical function in elderly. Clin Nutr 2008;27:189-195.

(30) Grossmann M, Hoermann R, Gani L, Chan I, Cheung A, Gow PJ, et al. Low testosterone levels as an independent predictor of mortality in men with chronic liver disease. Clin Endocrinol (Oxf) 2012;77:323-328.

(31) García PS, Cabbabe A, Kambadur R, Nicholas G, Csete M. Brief-reports: elevated myostatin levels in patients with liver disease: a potential contributor to skeletal muscle wasting. Anesth Analg 2010;111:707-709.

(32) Dasarathy S. Consilience in sarcopenia of cirrhosis. J Cachexia Sarcopenia Muscle 2012;3:225-237.

(33) Volpi E, Mittendorfer B, Rasmussen BB, Wolfe RR. The response of muscle protein anabolism to combined hyperaminoacidemia and glucose-induced hyperinsulinemia is impaired in the elderly. J Clin Endocrinol Metab 2000;85: 4481-4490

（34）駒井さつき，渡邊 裕，藤原佳典，金 憲経，枝広あ や子, 河合 恒, 他. 日本の地域在住高齢者に抢ける 栄養状態とサルコペニア重症度の関連性の検討 BMI, Alb, 体重減少の有無との関連. 日本老年医学 会雑誌 2016;53:387-395.

(35) Hara $N$, Iwasa $M$, Sugimoto R, Mifuji-Moroka R, Yoshikawa K, Terasaka E, et al. Sarcopenia and Sarcopenic Obesity Are Prognostic Factors for Overall Survival in Patients with Cirrhosis. Intern Med 2016;55:863-870.

(36) Shih R, Wang Z, Heo M, Wang W, Heymsfield SB. Lower limb skeletal muscle mass: development of dual-energy X-ray absorptiometry prediction model. J Appl Physiol 2000;89:1380-1386. 